\title{
Modifikasi Teknik Budidaya untuk Menurunkan Salinitas Lahan pada Tebu (Saccharum Officinarum L.) Lahan Kering di PG Cepiring Kendal
}

\author{
The Modification of Cultivation for Decreasing Salinity in Sugarcane (Saccharum officinarum \\ L.)Dryland in PG Cepiring Kendal
}

\section{Antonius Hari Kristanto dan Purwono*}

\author{
"Departemen Agronomi dan Hortikultura, Fakultas Pertanian, Institut Pertanian Bogor \\ (Bogor Agricultural University), Jl. Meranti, Kampus IPB Darmaga, Bogor 16680, Indonesia \\ Telp.\&Faks.62-251-8629353 e-mail agronipb@indo.net.id \\ *Penulis untuk korespondensi: purwono@yahoo.com
}

Disetujui 6 November 2017/Published online 14 November 2017

\begin{abstract}
The improvement program for increasing sugarcane production with extensification still faced a lot of problem. The highly convertion rate from agriculture area to nonagriculture was one of problem. The difficulity of searching ideal area for sugarcane cultivation have forced practitioners for planting sugarcane in marginal area. One type of marginal area for sugarcane cultivation was saline area. The sugarcane cultivation technic in saline area need special modification for decreasing salinity level that can cause physiology stess in sugarcane growth. The purpose of this observation was identify special modification technic of sugarcane cultivation in saline area, and study the growth, production, and economic analysis of sugarcane farming there. The observation was done in one plantation block of saline sugarcane plantation and nonsaline sugarcane plantation. The observation showed the modification of saline area cultivation technic in PG Cepiring was in irrigation technic that use basin-furrow method for decreasing salinity level. This method could reduce soil salinity into normal level in the ending of vegerative growth. The observation in sugarcane growth showed that the growth was obstructed in early vegetative phase because of salinity effect. This coused production of sugarcane in saline land was lower than in nonsaline land. Based on economic analysis of sugarcane farming, the profit of sugarcane farming in saline land and nonsaline land were not significantly different.
\end{abstract}

Keywords : sugarcane, saline area, modification cultivation technic, basin-furrow method

\begin{abstract}
ABSTRAK
Program peningkatan untuk meningkatkan produksi tebu dengan ekstensifikasi masih menghadapi banyak masalah. Tingginya tingkat konversi untuk area pertanian ke nonpertanian adalah salah satu masalahnya. Sulitnya mencari daerah yang ideal untuk budidaya tebu telah memaksa praktisi untuk menanam tebu di daerah marginal. Salah satu jenis daerah marginal untuk budidaya tebu adalah daerah salin. Teknik budidaya tebu di daerah salin perlu modifikasi khusus untuk mengurangi tingkat kesalinan yang dapat menyebabkan fisiologi dalam pertumbuhan tebu. Tujuan dari penelitian ini adalah mengidentifikasi teknik modifikasi khusus budidaya tebu di daerah salin, dan mempelajari pertumbuhan, produksi, dan analisis ekonomi dari petani tebu. Pengamatan dilakukan dalam satu blok perkebunan tebu daerah salin dan perkebunan tebu non salin. Pengamatan menunjukkan modifikasi dari teknik budidaya daerah saline di PG Cepiring dalam teknik irigasi yang menggunakan metode kolam-alur untuk mengurangi tingkat salinitas. Metode ini bisa mengurangi salinitas tanah ke tingkat normal pada akhir dari pertumbuhan vegerative. Pengamatan pertumbuhan tebu menunjukkan bahwa pertumbuhan terhalang pada fase vegetatif awal karena efek salinitas. Produksi ini tebu di lahan salin lebih rendah daripada di tanah non salin. Berdasarkan analisis ekonomi usahatani tebu, keuntungan usahatani tebu di lahan salin dan tanah nonsalin tidak berbeda nyata.
\end{abstract}

Kata kunci : daerah salin, metode kolam-alur, modifikasi teknik budidaya, tebu 


\section{PENDAHULUAN}

Dewasa ini masih terjadi masalah dalam kecukupan produksi gula untuk kebutuhan dalam negeri. Produksi gula dalam negeri baru sekitar 2.3 juta ton. Sementara itu, Indonesia membutuhkan 4.85 juta ton gula yang terdiri dari 2.7 juta ton untuk konsumsi langsung dan 2.15 juta ton untuk keperluan industri (Kementrian Pertanian, 2011).

Kesenjangan antara produksi gula dan kebutuhan gula dalam negeri membutuhkan upaya untuk mengatasinya. Kegiatan ekstensifikasi telah dilakukan pemerintah dengan berusaha menambah luasan areal pertanaman tebu. Program peningkatan produksi tebu dengan ektensifikasi menemui berbagai kendala. Tingginya laju konversi lahan pertanian menjadi lahan nonpertanian merupakan penghambat program ini. Semakin sulitnya menemukan lahan untuk areal pertanaman tebu memaksa berbagai pihak untuk menanam tebu di lahan marginal yang sulit untuk pertanaman tebu, salah satu contohnya adalah lahan di dekat pesisir laut dengan cekaman salinitas. Lahan salin mempunyai potensi untuk dimanfaatkan sebagai perkebunan tebu. Total lahan salin yang mencapai 0.44 juta ha di Indonesia merupakan potensi untuk upaya ektensifikasi perkebunan tebu (Alihamsyah dan Noor, 2003).

Penanaman tebu di lahan dengan salinitas tinggi membutuhkan teknik budidaya yang khusus. Teknik budidaya ini bertujuan untuk mengurangi dampak negatif dari tingginya kadar garam yang dapat menyebabkan cekaman fisiologi pada tebu (Santoso, 1993). Beberapa teknik budidaya khusus sebenarnya telah diterapakan, seperti pada kebun tebu PG Cepiring IGN. Teknik budidaya tersebut dilakukan untuk mengurangi kadar garam pada lahan sehingga memungkinkan tebu untuk bertahan dan tumbuh di lahan tersebut (Dirjen Pendidikan Tinggi, 1991).

Kegiatan ini mempelajari pengelolaan perkebunan tebu serta mempelajari budidaya, pertumbuhan dan produksi tebu di lahan tercekam salinitas di PG Cepiring. Hasil yang didapat diharapkan menjadi referensi untuk diterapkan di tempat lain berkenaan dengan budidaya tebu tercekam salinitas.

\section{METODE PENELITIAN}

Kegiatan dilaksanakan di Pabrik Gula Cepiring, Kendal, Jawa Tengah pada tanggal 14 Februari sampai 14 Juni 2011, Kegiatan pengamatan dilaksanakan di kebun Pidodo, yaitu kebun dengan salinitas tinggi, dan kebun Gondang, yaitu kebun dengan kondisi yang normal.

Pengamatan yang dilakukan adalah teknik budidaya, pertumbuhan tanaman, produksi kebun, serta analisis usaha tani pada kebun tebu lahan kering dengan salinitas tinggi. Pengamatan ini dipusatkan di kebun Pidodo yang termasuk kebun dengan salinitas tinggi yang terletak di pesisir laut utara Jawa. Semua pengamatan pada kebun Pidodo tersebut akan dibandingkan dengan pengamatan yang sama pada kebun Gondang, yaitu kebun tebu lahan kering normal yang tidak tercekam salinitas.

Kegiatan pengumpulan data yang akan membantu menganalisis aspek yang akan diperdalam. Pengumpulan data dilakukan dengan dua metode, yaitu metode langsung untuk data primer dan metode tidak langsung untuk data sekunder.

Pengumpulan data primer dilakukan melalui pengamatan terhadap semua kegiatan yang berlangsung di lapangan, wawancara dan diskusi dengan buruh harian lepas, mandor maupun dengan para staf.

Pengamatan dan analisis dilakukan untuk mengetahui pertumbuhan dan produktivitas tebu dengan cekaman salinitas, serta teknik budidaya yang diterapkan di kebun tersebut. Pengamatan tebu yang tercekam salinitas ini dilakukan di kebun Pidodo, yaitu kebun di pesisir pantai utara Jawa yang berjarak $1 \mathrm{~km}$ dari pantai, sehingga terkendala dengan salinitas yang tinggi.

Pengamatan juga akan dilakukan pada kebun yang tidak terkendala salinitas sebagai pembanding. Variabel pengamatan di kebun ini sama seperti yang diterapkan di kebun terkendala salinitas. Pengamatan tebu sebagai pembanding ini dilakukan di kebun Gondang, yaitu kebun sawah tadah hujan yang tidak terkendala dengan salinitas.

Pengamatan di kedua kebun dilakukan pada satu blok untuk masing-masing kebun. Setiap blok diambil satu petak contoh. Setiap petak contoh diambil lima bak tanam tebu sebagai ulangan. Setiap bak tanam tebu diambil empat juringan contoh. Setiap juringan contoh terdapat satu tanaman contoh, sehingga terdapat empat tanaman contoh pada setiap ulangan. Kategori tanaman yang diamati adalah RC I (Ratoon Cane) atau tebu keprasan pertama.

Penentuan contoh dilakukan dengan metode acak dan sistematis, disesuaikan dengan keadaan kebun dan homogenitasnya (Mantra dan Kasto, 2008). Blok dan petak contoh dipilih secara acak. Bak contoh untuk kebun Gondang dipilih secara sistematis karena lingkungan yang homogen. Bak 
contoh untuk kebun Pidodo dipilih dengan menyesuaikan keadaan lahan karena tingkat homogenitasnya yang rendah dan kondisi kebun yang sulit terjangkau. Penentuan juringan dan tanaman contoh untuk kedua kebun dilakukaan dengan cara sistematis.

Beberapa variabel pengamatan yang dilakukan meliputi

(a) tinggi batang, (b) diameter batang, (c) jumlah ruas batang, (d) jumlah batang dan jumlah sogolan per meter juringan, (e) umur berbunga, (f) brix nira, (g) Electronic Conductivity (EC) dan salinitas tanah, (h) tata Layout Kebun, (i) produktivitas, dan (j) analisis usaha tani.

Pengukuran variabel pengamatan disesuaikan dengan kondisi kebun. Pengukuran variabel pertumbuhan dilakukan setiap 4 minggu, mulai tanaman berumur 27 MSK (Minggu Setelah Keprasan) sampai 39 MSK. Variabel pertumbuhan tersebut antara lain tinggi batang, diameter batang, dan jumlah ruas batang. Pengamatan jumlah batang (27 MSK) dan sogolan per meter juringan (41 MSK), EC tanah dan tata layout kebun (35 MSK) dilakukan satu kali. Pengamatan brix nira dilakukan dua kali pada 27 MSK dan 41 MSK.

Data yang diperoleh dari setiap variabel pengamatan dianalisis menggunakan analisis statistika. Pengamatan pada variabel yang meliputi tinggi batang, jumlah ruas, diameter batang, brix nira, jumlah batang dan sogolan per meter juringan diuji menggunakan uji $\mathrm{t}$ dengan membandingkan variabel pengamatan tersebut pada kedua kebun contoh setiap kali pengamatan. Uji $\mathrm{t}$ juga dilakukan untuk membandingkan pertumbuhan tanaman pada kedua kebun melalui selisih setiap variabel pengamatan antara 27 MST dan 41 MST. Uji t juga dilakukan pada produktivitas tebu. Analisis deskriptif dilakukan pada pengamatan tata layout kebun, nilai EC, salinitas tanah, dan perolehan keuntungan pada analisis usaha tani.

\section{HASIL DAN PEMBAHASAN}

Terdapat kebun tebu di area PG Cepiring yang terdapat di lahan salin. Pengamatan dilakukan di kebun Pidodo dengan luasan 24.80 ha yang terdiri dari tiga blok, yaitu Pidodo A dengan luasan 10.00 ha, Pidodo B dengan luasan 14.26 ha, dan Pidodo C dengan luasan 0.53 ha. Kebun Pidodo terletak di pesisir pantai utara jawa dengan jarak sekitar $1 \mathrm{~km}$ dari bibir pantai. Kebun Pidodo terletak di muara sungai Bodri yang sering mengalami banjir pasang air laut dan meluap ke kebun dengan membawa kandungan air laut. Kebun Pidodo terletak di kecamatan Patebon dengan curah hujan yang cukup tinggi yaitu antara $1500-3500 \mathrm{~mm} / \mathrm{tahun}$. Kondisi geografis yang demikian menyebabkan kebun Pidodo terkendala salinitas akibat adanya banjir air pasang yang sering terjadi. Hal ini sesuai dengan pendapat Santoso (1993), yang menyatakan bahwa proses salinisasi daerah dengan curah hujan tinggi terjadi di delta sungai yang terpengaruh air laut dan pantai yang letaknya rendah. Ciri salinitas yang tinggi pada kebun Pidodo juga dilihat dari terbentuknya efflorescense atau kerak garam yang terjadi pada musim kering.

\section{Kondisi Salinitas Kebun}

Pengamatan salinitas pada kebun dilakukan melalui analisis daya hantar listrik tanah dan konsentrasi garam. Analisis tanah dilakukan pada saat tebu berumur 35 MSK dengan kondisi tidak terdapat hujan selama 14 hari. Selain melakukan analisis tanah kebun Pidodo, dilakukan analisis tanah kebun Gondang sebagai pembanding untuk lahan tidak tercekam salinitas. Hasil pengamatan dapat dilihat pada Tabel 1.

Tabel 1. Analisis salinitas tanah saat tebu berumur 31 MSK

\begin{tabular}{ccc}
\hline Kebun & $\begin{array}{c}\text { Daya Hantar Listrik } \\
(\mathrm{dS} / \mathrm{m})\end{array}$ & $\begin{array}{c}\text { Salinitas } \\
(\mathrm{mg} / \mathrm{l})\end{array}$ \\
\hline Pidodo & 0.168 & 79 \\
Gondang & 0.108 & 50 \\
\hline
\end{tabular}

Menurut Cresser et al. (1993), kriteria tanah salin adalah tanah dengan daya hantar listrik (DHL) lebih dari $2 \mathrm{dS} / \mathrm{m}$. Tanah dengan DHL kurang dari $2 \mathrm{dS} / \mathrm{m}$ tergolong nonsalin dengan pengaruh salinitas terhadap tanaman dapat diabaikan. Berdasarkan pendapat tersebut, meskipun nilai DHL kebun Pidodo lebih besar dari Gondang sebagai kontrol lahan nonsalin, kebun Pidodo masih tergolong lahan nonsalin pada pengamatan tebu berumur $31 \mathrm{MSK}$.

Berdasarkan hasil berikut, dapat diketahui bahwa kondisi salinitas kebun Pidodo dapat diabaikan. Hal ini menunjukkan bahwa teknik tata air melalui metode kolam-alur (basin-furrow method) yang diterapkan di lahan Pidodo dapat menurunkan tingkat salinitas lahan sampai ke golongan nonsalin pada umur tebu 31 MST, yaitu pada bulan April. Hal ini sesuai dengan pendapat Santoso (1993), pencucian air dan perbaikan drainase dapat memperbaiki tanah-tanah salin. 
Tabel 2. Curah hujan kebun pidodo pada stasiun hujan terdekat

\begin{tabular}{lccccc}
\hline \multirow{2}{*}{ Bulan } & \multicolumn{5}{c}{ Tahun } \\
\cline { 2 - 6 } & 2006 & 2007 & 2008 & 2009 & 2010 \\
\hline \multirow{3}{*}{ Januari } & $\ldots \ldots \ldots \ldots \ldots \ldots$ & 110 & 238 & 245 & 231 \\
Februari & 246 & 224 & 897 & 376 & 169 \\
Maret & 131 & 261 & 108 & 57 & 177 \\
April & 108 & 252 & 61 & 64 & 73 \\
Mei & 30 & 58 & 69 & 67 & 208 \\
Juni & 22 & 79 & 26 & 102 & 136 \\
Juli & 18 & 25 & 0 & 26 & 41 \\
Agustus & 0 & 49 & 6 & 26 & 107 \\
September & 0 & 0 & 11 & 20 & 222 \\
Oktober & 0 & 54 & 151 & 16 & 232 \\
November & 74 & 66 & 82 & 34 & 207 \\
Desember & 123 & 248 & 218 & 78 & 333 \\
\hline
\end{tabular}

Penurunan salinitas ini juga dipengaruhi oleh curah hujan yang tinggi di kebun Pidodo pada bulan Januari sampai Maret sehingga termasuk bulan basah (Kartasapoetra, 2008). Hal ini dapat terlihat dari data pengamatan curah hujan selama 5 tahun terakhir dari stasiun hujan terdekat (Tabel 2). Pengaruh tingginya curah hujan terhadap penurunan tingkat salinitas ini sesuai dengan pendapat Tan (1991), bahwa salinitas akan berkurang dengan adanya curah hujan yang tinggi pada daerah beriklim basah.

\section{Teknis Budidaya Tebu di Lahan Salin}

Teknis budidaya tebu yang diterapkan di lahan tercekam salinitas secara umum sama dengan kebun lain yang tidak terkendala salinitas. Semua teknis budidaya diterapkan sesuai dengan standar perusahaan, mulai dari pembukaan lahan, penanaman, pemeliharaan tanaman hingga tebang dan angkut. Teknis budidaya yang berbeda di lahan salin adalah sistem tata air melalui got kebun.

Sistem tata air yang berbeda diterapkan pada kebun yang terkendala salinitas yang tinggi. Kebun dengan kendala salinitas biasanya terdapat di daerah pesisir pantai utara. Kebun ini kadang mengalami banjir air laut pasang (rob) yang membawa air laut masuk ke kebun sehingga meningkatkan kadar garam tanah. Upaya yang dilakukan oleh PG Cepiring adalah pembuatan got besar dengan ukuran lebar $2 \mathrm{~m}$ dengan kedalaman $3 \mathrm{~m}$, sementara untuk kebun pada umumya got berukuran $50 \mathrm{~cm}$ pada lebar dan kedalaman 60 $\mathrm{cm}$. Panjang juringan tetap $8 \mathrm{~m}$ sehingga jumlah got di lahan salin lebih sedikit karena lebar dan dalamnya got jauh lebih besar.

Pembuatan got pada lahan tercekam salinitas dirancang untuk mengurangi efek salinitas dengan pencucian garam melalui irigasi dan drainase. Ukuran got yang besar dapat menampung dan mengalirkan air yang lebih banyak serta meningkatkan drainase. Got akan mengalirkan air ke kebun untuk mencuci garam yang terkandung di tanah secara berangsurangsur. Air yang mengalir biasanya akan tertampung di got dan menggenang selama beberapa waktu. Air yang dimasukkan untuk mencuci garam tersebut akan ditampung kembali oleh got untuk dapat dibuang keluar kebun melalui drainase yang baik.

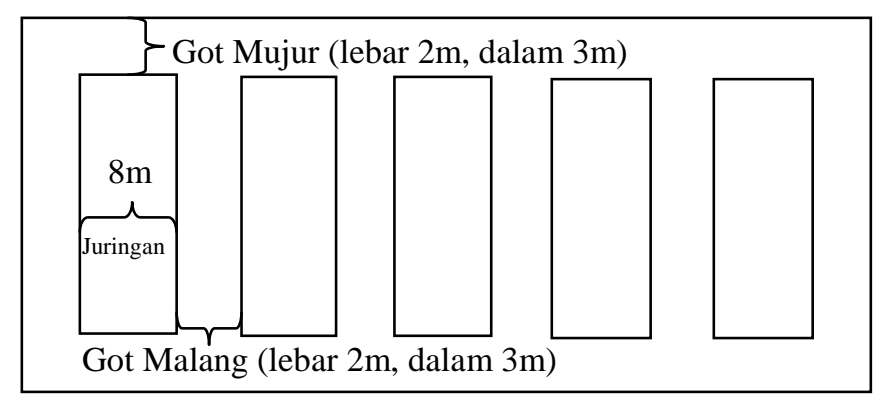

(a)

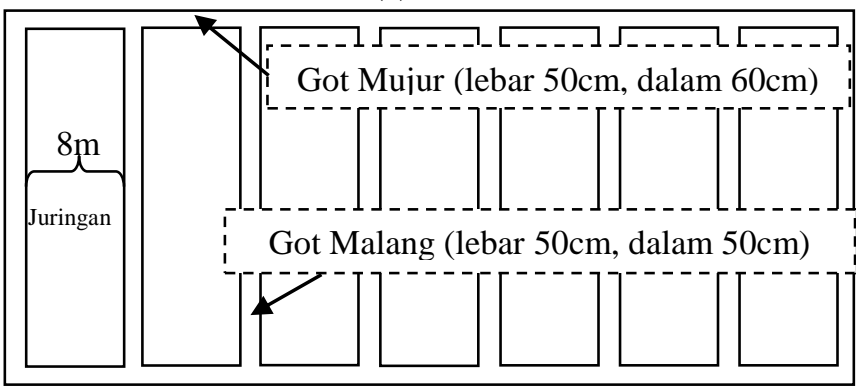

(b)

Gambar 1. Susunan Bak Tanam, Juringan, dan Got Kebun Salin (a) dan Nonsalin (b)

Pembuatan got pada lahan tercekam salinitas dirancang untuk mengurangi efek salinitas dengan pencucian garam melalui irigasi dan drainase. Ukuran got yang besar dapat menampung dan mengalirkan air yang lebih banyak serta meningkatkan drainase. Got akan mengalirkan air ke kebun untuk mencuci garam yang terkandung di tanah secara berangsurangsur. Air yang mengalir biasanya akan tertampung di got dan menggenang selama beberapa waktu. Air yang dimasukkan untuk mencuci garam tersebut akan ditampung kembali oleh got untuk dapat dibuang keluar kebun melalui drainase yang baik.

Menurut Santoso (1993), sistem irigasi dan got yang diterapkan di lahan tercekam salinitas oleh PG Cepiring disebut reklamasi lahan salin dengan metode kolam-alur (basin-furrow method). Metode ini akan mengalirkan air irigasi melalui parit (got) yang dibuat di sekeliling lahan. Air akan dipertahankan sekitar seminggu sampai seluruh lahan dapat diresapi air. Dengan sistem ini kepekatan garam akan tercuci aliran irigasi, 
sehingga kadar garam yang tinggi di lahan dapat diatasi.

Got dengan ukuran yang besar dapat mengurangi kerusakan lahan akibat banjir air pasang yang kerap terjadi di lahan tercekam salinitas yang terletak di pesisir pantai utara Jawa. Ketika banjir terjadi, air banjir akan tertampung di got sehingga mencegah air banjir dengan kandungan garam tinggi masuk ke juringan tebu. Hal ini dapat mencegah kerusakan fisik pada tebu juga mencegah peningkatan salinitas tanah pada kebun.

\section{Kondisi Tebu di Lanah Salin}

Kondisi tebu diamati pada fase vegetatif akhir sampai dengan fase generatif, ditandai dengan munculnya bunga pada tebu. Pengamatan dilakukan pada blok dengan varietas $\mathrm{BL}$ (Bululawang) keprasan pertama (RC 1). Pengamatan dilakukan setiap 4 minggu, dimulai 27 MSK (minggu setelah keprasan) sampai 39 MSK. Pengamatan juga dilakukan pada tebu yang tidak tercekam salinitas sebagai pembanding, yaitu kebun Gondang.

Hasil pengamatan tinggi tanaman (Tabel 3) menunjukkan tinggi tanaman kebun salin lebih rendah dan berbeda nyata pada seluruh minggu pengamatan. Hal ini menunjukkan pengaruh salinitas yang nyata terhadap tinggi tanaman tebu. Tebu di lahan salin mengalami cekaman dalam pertumbuhan tingginya. Hal ini sesuai dengan pendapat Santoso (1993) yang menyebutkan bahwa tanaman dengan cekaman salinitas akan mengalami penghambatan dari perpanjangan sel, sehingga tanaman tampak kerdil.

Hasil pengamatan jumlah ruas (Tabel 3) menunjukkan hasil yang tidak berbeda nyata pada seluruh minggu pengamatan. Hasil ini menunjukkan bahwa pertumbuhan anatomi tebu pada lahan salin sama seperti tebu pada umunya yang ditaman di kondisi nonsalin berdasarkan jumlah ruas batangnya. Dengan tinggi batang yang lebih rendah dan mempunyai jumlah ruas yang sama dengan tebu tak tercekam salinitas, panjang ruas tebu tercekam salinitas lebih pendek daripada tebu tak tercekam salinitas. Hal tersebut menunjukkan pembelahan sel pada tebu tercekam salinitas tetap berjalan, namun pemanjangan selnya terganggu. Hal ini sesuai dengan pendapat Santoso (1993) yang menyatakan pembelahan sel pada tanaman tercekam salinitas tetap berjalan secara kontinyu, namun pemanjangan selnya terhambat.
Tabel 3. Tinggi tanaman tebu, jumlah ruas, diameter, dan bobot batang pada 27 MSK sampai 41 MSK

\begin{tabular}{|c|c|c|c|c|c|}
\hline \multirow{2}{*}{$\begin{array}{c}\text { Pengamat } \\
\text { an }\end{array}$} & \multirow[t]{2}{*}{ Kebun } & \multicolumn{4}{|c|}{ Umur Tebu (MSK) } \\
\hline & & 27 & 31 & 35 & 39 \\
\hline \multirow{2}{*}{$\begin{array}{c}\text { Tinggi } \\
\text { tanaman } \\
(\mathrm{cm})\end{array}$} & Pidodo & $192.90 \mathrm{a}$ & $219.55 a$ & $233.60 \mathrm{a}$ & $240.60 \mathrm{a}$ \\
\hline & Gondang & $283.15 b$ & $305.85 b$ & $319.00 \mathrm{~b}$ & $334.10 b$ \\
\hline \multirow{2}{*}{$\begin{array}{l}\text { Jumlah } \\
\text { ruas }\end{array}$} & Pidodo & $17.20 \mathrm{a}$ & $19.25 \mathrm{a}$ & $21.50 \mathrm{a}$ & $22.70 \mathrm{a}$ \\
\hline & Gondang & $19.35 \mathrm{a}$ & $22.65 a$ & $24.80 \mathrm{a}$ & $26.80 \mathrm{a}$ \\
\hline \multirow{2}{*}{$\begin{array}{c}\text { Diameter } \\
\text { batang } \\
(\mathrm{cm})\end{array}$} & Pidodo & $2.24 \mathrm{a}$ & $2.32 \mathrm{a}$ & $2.38 \mathrm{a}$ & $2.39 \mathrm{a}$ \\
\hline & Gondang & $2.57 \mathrm{a}$ & $2.66 \mathrm{a}$ & $2.69 \mathrm{a}$ & $2.71 \mathrm{a}$ \\
\hline \multirow{2}{*}{$\begin{array}{c}\text { Bobot } \\
\text { batang } \\
(\mathrm{kg})\end{array}$} & Pidodo & $0.79 a$ & $0.94 \mathrm{a}$ & $1.03 \mathrm{a}$ & $1.06 \mathrm{a}$ \\
\hline & Gondang & $1.33 \mathrm{~b}$ & $1.49 \mathrm{~b}$ & $1.58 \mathrm{~b}$ & $1.67 \mathrm{~b}$ \\
\hline Keterangan & $\begin{array}{l}\text { Nilai seti } \\
\text { sama yan } \\
\text { tidak berb }\end{array}$ & nyata & asarka & t pada & $\begin{array}{l}\text { yang } \\
\text { jukkan } \\
5 \% \text {. }\end{array}$ \\
\hline
\end{tabular}

Hasil pengamatan diameter batang (Tabel 3) menunjukkan hasil yang tidak berbeda nyata pada seluruh minggu pengamatan. Hal ini menunjukkan cekaman salinitas tidak berpengaruh terhadap besarnya diameter tebu. Tebu yang merupakan tanaman monokotil memang tidak mengalami pembesaran batang karena tidak memiliki kambium di batang dan besarnya diameter dipengaruhi oleh pemupukan $\mathrm{N}$ pada tebu (James, 2004). Pengamatan diameter yang tidak berbeda nyata ini menunjukkan penyerapan nutrisi melaui akar tetap dapat berjalan dengan upaya reklamasi lahan salin dan teknik budidaya yang dilakukan di kebun tercekam salinitas.

Pengamatan bobot batang dilakukan menggunakan tabel konversi bobot batang per meter berdasarkan diameter batang. Berdasarkan perhitungan tersebut, selain dipengaruhi oleh varietasnya, bobot tebu akan dipengaruhi diameter dan panjang batangnya. Pada pengamatan bobot batang (Tabel 3), didapatkan bobot batang tebu tercekam salinitas yang lebih rendah dan berbeda nyata dengan kebun nonsalin pada setiap pengamatan. Hal tersebut menunjukkan bahwa meskipun upaya reklamasi dan teknik budidaya yang diterapkan di lahan salin dapat menghasilkan diameter batang yang sama dengan tebu di lahan nonsalin, bobot perbatang tebu tetap lebih rendah dari tebu nonsalin. Hal ini disebabkan pertumbuhan tinggi tebu tercekam salinitas sangat terhambat (Tabel 3). Bobot batang yang rendah pada kebun salin akan mempengaruhi jumlah panen yang didapatkan.

Pengamatan jumlah batang tebu dan sogolan (Tabel 4) menunjukkan hasil yang tidak berbeda nyata antara kebun salin dengan kebun nonsalin. 
Tabel 4. Jumlah batang tebu dan Sogolan per meter juringan

\begin{tabular}{ccc}
\hline Kebun & $\begin{array}{c}\text { Jumlah batang } \\
\text { per meter }\end{array}$ & $\begin{array}{c}\text { Jumlah sogolan } \\
\text { per meter }\end{array}$ \\
\hline $\begin{array}{c}\text { Pidodo (Salin) } \\
\text { Gondang }\end{array}$ & $11.08 \mathrm{a}$ & $2.63 \mathrm{a}$ \\
(Nonsalin) & $10.04 \mathrm{a}$ & $2.18 \mathrm{a}$
\end{tabular}

Keterangan : Nilai pada kolom yang sama yang diikuti oleh huruf yang sama menunjukkan tidak berbeda nyata berdasarkan uji T pada taraf $5 \%$.

Banyaknya jumlah batang menggambarkan kondisi pertumbuhan tunas-tunas baru setelah keprasan, sedangkan jumlah sogolan menggambarkan pertumbuhan tunas-tunas susulan yang tumbuh menjelang fase generatif tebu. Hasil pengamatan yang didapatkan menunjukkan bahwa upaya reklamasi lahan salin dan teknis budidaya tebu yang diterapkan di lahan salin dapat menghilangkan pengaruh salinitas dalam menghambat pertumbuhan tunas-tunas baru.

Tabel 5. Brix nira tebu di lapang pada umur 27 MSK dan 41 MSK

\begin{tabular}{|c|c|c|}
\hline \multirow[t]{2}{*}{ Kebun } & \multicolumn{2}{|c|}{ Umur (MSK) } \\
\hline & 27 & 41 \\
\hline & & \\
\hline $\begin{array}{l}\text { Pidodo } \\
\text { (Salin) }\end{array}$ & $14.87 \mathrm{a}$ & $24.13 \mathrm{a}$ \\
\hline $\begin{array}{l}\text { Gondang } \\
\text { (Nonsalin) }\end{array}$ & $15.60 \mathrm{a}$ & $24.13 \mathrm{a}$ \\
\hline
\end{tabular}

Keterangan : Nilai pada kolom yang sama yang diikuti oleh huruf yang sama menunjukkan tidak berbeda nyata berdasarkan uji T pada taraf $5 \%$.

Brix nira tebu di lapang akan menggambarkan rendemen tebu ketika diolah menjadi gula. Berdasarkan pengamatan didapatkan bahwa nilai brix kebun salin dan kebun nonsalin tidak berbeda nyata pada pengukuran 27 MSK dan 41 MSK. Hal tersebut menunjukkan upaya reklamasi dan teknik budidaya tebu yang diterapkan di kebun salin dapat menghilangkan pengaruh buruk cekaman salinitas dalam pembentukan dan penyimpanan sukrosa pada tebu. Hal ini disebabkan oleh upaya reklamasi yang dilakukan dapat mencegah pengaruh salinitas dalam menghambat penyerapan hara (Santoso,1993). Penyerapan unsur hara yang baik oleh tanaman dapat meningkatkan rendemen. Selain itu, rendemen yang sama pada kedua kebun juga dipengaruhi oleh teknik budidaya yang sama pada kedua kebun selain tata air, karena rendemen tebu dipengaruhi oleh teknis budidaya yang diterapkan (Supriyadi, 1992).

\section{Pertumbuhan dan Pembungaan Tebu di Lahan} Salin

Pertumbuhan tebu di lahan salin diamati pada fase vegetatif akhir sampai fase generatif dengan ditandai tebu berbunga. Pengamatan pertumbuhan dilakukan pada veriabel tinggi batang, jumlah ruas, diameter batang, dan bobot batang. Nilai pertumbuhan dari masing-masing variabel adalah selisih nilai variabel pada pengamatan 41 MSK dan 27 MSK.

Tabel 6. Pertumbuhan Tebu di Kebun Salin dan Nonsalin pada 27 MSK Sampai 41 MSK

\begin{tabular}{lcc}
\hline \multicolumn{1}{c}{ Peubah } & $\begin{array}{c}\text { Kebun } \\
\text { Pidodo } \\
\text { (Salin) }\end{array}$ & $\begin{array}{c}\text { Kebun } \\
\text { Gondang } \\
\text { (Nonsalin) }\end{array}$ \\
\hline Tinggi tanaman $(\mathrm{cm})$ & $47.70 \mathrm{a}$ & $50.96 \mathrm{a}$ \\
Diameter batang $(\mathrm{cm})$ & $0.15 \mathrm{a}$ & $0.14 \mathrm{a}$ \\
Jumlah ruas & $5.50 \mathrm{a}$ & $7.45 \mathrm{a}$ \\
Bobot batang $(\mathrm{kg})$ & $0.27 \mathrm{a}$ & $0.34 \mathrm{a}$
\end{tabular}

Keterangan : Nilai pada baris yang sama yang diikuti oleh huruf yang sama menunjukkan tidak berbeda nyata berdasarkan uji $\mathrm{T}$ pada taraf $5 \%$

Pengamatan pertumbuhan (Tebel 9) menunjukkan pertumbuhan tebu selama 27 MSK sampai 41 MSK menunjukkan hasil yang tidak berbeda nyata untuk seluruh peubah pengamatan. Hasil pengamatan menujukkan bahwa pertumbuhan tebu di lahan salin pada periode pengamatan tersebut tidak berbeda dengan pertumbuhan tebu di lahan nonsalin. Hal ini menunjukkan pengaruh buruk salinitas pada pertumbuhan tebu tidak terjadi pada periode tersebut. Hal ini didukung dengan hasil analisis salinitas tanah di lahan salin yang menunjukkan tingkat salinitas yang redah dan dapat ditolerir oleh tanaman (Tabel 1).

Meskipun pertumbuhan tebu pada periode pengamatan 27 MSK sampai 41 MSK tidak terpengaruh oleh salinitas, kondisi tanaman tebu di lahan salin menunjukkan hasil yang lebih rendah berdasarkan pengamatan tinggi tanaman (Tabel 3). Hal ini menunjukkan bahwa efek buruk salinitas terhadap pertumbuhan tebu terjadi pada masa pertumbuhan vegetatif awal setelah keprasan. Efek buruk salinitas yang terjadi pada masa vegetatif awal dikarenakan curah hujan pada masa tersebut rendah. Terjadi curah hujan yang rendah pada bulan Juli sampai September (Tabel 2), sehingga digolongkan bulan kering (Kartasapoetra, 2008). Curah hujan yang rendah pada bulan tersebut mengakibatkan tingkat salinitas pada kebun salin bertambah dan menghambat pertumbuhan tinggi batang tebu pada fase vegetatif awal setelah keprasan. Hal ini sesuai pendapat Santoso (1993) yang menyatakan 
bahwa proses salinisasi akan bertambah karena curah hujan yang kurang untuk malarutkan dan mencuci garam.

Salinitas juga berpengaruh pada pembungaan tebu. Pembungaan tebu yang diamati pada kedua kebun menunjukkan sifat pembungaan tebu secara sporadis (pembungaan yang tidak seragam). Tebu di lahan salin Pidodo mulai berbunga secara sporadis pada 33 MSK, sedangkan tebu di lahan nonsalin Gondang mulai berbunga secara sporadis pada 37 MSK. Hal ini menunjukkan efek salinitas berpengaruh pada percepatan pembungaan pada tebu, meskipun telah dilakukan upaya reklamasi lahan dan teknis budidaya di lahan salin. Hal ini sesuai dengan pendapat Hadisaputro (2008) yang menyatakan bahwa cekaman air pada lahan salin dapat mendorong pembungaan tebu.

\section{Produktivitas Tebu dan Analisis Usaha Tani Kebun Tebu di Lahan Salin}

Produksi tebu di lahan salin diamati sejak masa tanam pertama di kebun pengamatan bersadarkan data sekunder. Produksi untuk masa tanam 2010/2011 didapatkan berdasarkan taksasi Maret.

Tabel 7. Produktivitas Tebu di Lahan Salin dan Nonsalin Selama Tiga Musim Tanam

\begin{tabular}{|c|c|c|c|c|}
\hline \multirow[b]{2}{*}{ Kebun } & \multicolumn{3}{|c|}{ Masa Tanam } & \multirow{2}{*}{$\begin{array}{c}\text { Rata-rata } \\
\text { Produktivi } \\
\text { tas }\end{array}$} \\
\hline & $\begin{array}{c}2008 / 20 \\
09 \\
\end{array}$ & $\begin{array}{c}2009 / 20 \\
10 \\
\end{array}$ & $\begin{array}{c}2010 / 20 \\
11 \\
\end{array}$ & \\
\hline \multirow{3}{*}{$\begin{array}{l}\text { Pidodo } \\
\text { Gonda } \\
\text { ng }\end{array}$} & & ........to to & ha......... & \\
\hline & 45.02 & 66.86 & 64.75 & $58.87 \mathrm{a}$ \\
\hline & 84.54 & 107.89 & 96.78 & $96.40 \mathrm{~b}$ \\
\hline
\end{tabular}

Produktivitas tebu di lahan salin berbeda nyata dan lebih rendah daripada lahan nonsalin. Hal ini menunjukkan upaya reklamasi lahan dan teknik budidaya yang telah dilakukan di kebun salin belum mampu membuat tebu berproduksi seperti lahan nonsalin. Hal ini juga menunjukkan pengaruh dari salinitas tetap terjadi pada lahan salin dan mengakibatkan rendahnya produktivitas tebu. Namun produktivitas kebun salin menunjukkan peningkatan selama tiga musim tanam. Hal ini menunjukkan bahwa pengaruh buruk salinitas terhadap tanaman berangsurangsur berkurang dan dapat diketahui bahwa upaya reklamasi dan teknik budidaya tebu yang telah diterapkan sejak masa tanam 2008/2009 dapat mengurangi efek buruk salinitas secara berangsur-angsur sampai pengamatan pada masa tanam 2010/2011.

Tabel 8. Keuntungan Usaha Tani Tebu di Kebun Salin dan Nonsalin Masa Tanam 2010/2011

\begin{tabular}{|c|c|c|c|}
\hline \multirow{2}{*}{$\begin{array}{l}\text { Kategori } \\
\text { tanaman }\end{array}$} & \multirow{2}{*}{$\begin{array}{l}\text { Rincian } \\
\text { usaha tani }\end{array}$} & \multicolumn{2}{|c|}{ Kebun } \\
\hline & & Pidodo (Salin) & $\begin{array}{c}\text { Gondang } \\
\text { (Nonsalin) }\end{array}$ \\
\hline \multirow{3}{*}{$\mathrm{PC}$} & Biaya & Rp 21359982.43 & Rp 40782615.66 \\
\hline & Pendapatan & Rp 27072059.23 & Rp 43553880.19 \\
\hline & Keuntungan & $\mathrm{Rp} \quad 5712076.80$ & Rp 2771264.53 \\
\hline \multirow{3}{*}{ RCI } & Biaya & Rp 19299706.84 & Rp 32843869.35 \\
\hline & Pendapatan & Rp 26915799.14 & Rp 46704218.40 \\
\hline & Keuntungan & Rp 7616092.30 & Rp 13860349.05 \\
\hline \multirow{3}{*}{ RCII } & Biaya & Rp 19962214.46 & $\operatorname{Rp} 30630539.30$ \\
\hline & Pendapatan & Rp 30626976.09 & Rp 34815673.26 \\
\hline & Keuntungan & Rp 10664761.63 & Rp $\quad 4185133.96$ \\
\hline \multirow{3}{*}{ Rata-rata } & Biaya & Rp 20207301.25 & Rp 34752341.44 \\
\hline & Pendapatan & Rp 28204944.82 & Rp 41691257.28 \\
\hline & Keuntungan & Rp 7997643.58 & $\mathrm{Rp} \quad 6938915.85$ \\
\hline
\end{tabular}

Rata-rata keuntungan antara lahan salin dan nonsalin menunjukkan hasil yang tidak jauh berbeda (Tabel 8). Hal ini menunjukkan perolehan keuntungan dari usaha tebu di kedua lahan tersebut sama, meskipun produksi tebu di lahan nonsalin jauh lebih tinggi daripada lahan salin. Hal ini diakibatkan oleh biaya sewa lahan yang jauh berbeda. Biaya sewa lahan di lahan nonsalin yang merupakan lahan subur sangat tinggi. Hal ini diakibatkan juga oleh persaingan dengan komoditas lain di lahan nonsalin sehingga menyebabkan biaya sewa lahan yang tinggi. Biaya sewa di lahan salin jauh lebih rendah diakibatkan oleh letak lahan yang kurang strategis serta kesuburan lahan yang rendah akibat cekaman salinitas. Hal ini menyebabkan tidak adanya persaingan dengan komoditas lain di lahan salin yang menyebabkan rendahnya biaya sewa lahan.

\section{KESIMPULAN}

Modifikasi teknik budidaya yang diterapkan di lahan tercekam salinitas yaitu pada teknik tata air yang menggunakan metode kolamalur (basin-furrow method) untuk menurunkan salinitas lahan. Perlakuan khusus yang diterapkan di lahan tercekam salinitas dapat menurunkan tingkat salinitas lahan berdasarkan pengamatan menjelang fase generative tebu, namun pertumbuhan tebu tetap terhambat pada fase vegetatif awal. Akibat hambatan pertumbuhan tersebut, produksi tebu di lahan salin lebih rendah daripada lahan nonsalin. Berdasarkan analisis usaha tani, usaha tani tebu di lahan salin tetap menguntungkan dan tidak jauh berbeda dengan lahan nonsalin. 


\section{DAFTAR PUSTAKA}

Alihamsyah, T., I. Noor. 2003. Lahan Rawa Pasang Surut Pendukung Ketahanan Pangan dan Sumber Pertumbuhan Agribisnis. Balai Penelitian Lahan Rawa. Jakarta. 46 hal.

Cresser, M., K. Killham, T. Edwards. 1995. Soil Chemistry and Its Application. Cambridge (UK): Cambridge University Press. 192p

Dirjen Pendidikan Tinggi.1991. Kimia Tanah. Departemen Pendidikan dan Kebudayaan. Jakarta. 232 hal

Hadisaputro, S. 2008.Tebu berbunga rendemen tinggi. [interent] [ tersedia pada 2011 Mar 17] http://sugarresearch.org/wpcontent/uploads/20 08/12/tebu-berbunga-rendemen-tinggi.pdf.

James, G. 2004. Sugarcane. Second Edition. Blackwell. Kundli. 256 p.

Kartasapoetra, A.G. 2008. Klimatologi: Pengaruh Iklim Terhadap Tanah dan Tanaman. Jakarta (ID): Bumi Aksara.. 101 hal.
Kementrian Pertanian. 2009. Basis data statistik pertanian. [internet] [tersedia pada $2010 \mathrm{Mar}$ 09] http://database.deptan. go.id.

Mantra, I. B. dan Kasto. 2008. Penentuan sampel, hal. 149-174. Dalam M. Singarimbun dan S. Effendi (Eds.). Metode Penelitian Survai. Jakarta (ID): Pustaka LP3ES.

Santoso, B. 1993. Tanah Salin-Tanah Sodik dan Cara Mereklamasinya. Malang (ID): Yayasan Pembina Fakultas Pertanian Universitas Brawijaya. 63 hal.

Supriyadi, A. 1992. Rendemen Tebu Liku-Liku Permasalahannya. Jakarta (ID): Kanisius. 72 hal.

Sutardjo, E. R. M. 2002. Budidaya Tanaman Tebu. Jakarta (ID): Bumi Aksara. 76 hal

Tan, K.H.1991.Dasar-Dasar Kimia Tanah (diterjemahkan dari: Principles of Soil Chemistry, penerjemah: D.H.Goenadi). Yogyakarta (ID): Gadjah Mada University Press. 295 hal. 